\title{
The Crimean Tatar nationalist organization "Conscience" : Fact or
} police invention?

\section{Hakan Kirimli}

\section{Citer ce document / Cite this document :}

Kirimli Hakan. The Crimean Tatar nationalist organization "Conscience" : Fact or police invention?. In: Cahiers du monde russe : Russie, Empire russe, Union soviétique, États indépendants, vol. 37, n³, Juillet-septembre 1996. pp. 277-290;

doi : https://doi.org/10.3406/cmr.1996.2461

https://www.persee.fr/doc/cmr_1252-6576_1996_num_37_3_2461

Fichier pdf généré le 12/05/2018 


\begin{abstract}
Hakan Kirimu, The Crimean Tatar nationalist organization "Conscience " : Fact or police invention? It is known that during the early 1910's there was a remarkable degree of underground nationalistic activities among the Crimean Tatars, some of which were connected with the "Fatherland Society" which had been founded by the Crimean Tatar students in Turkey. The recently disclosed documents in the archives of the tsarist police attribute most of such activities in 1910 to a certain Crimean Tatar nationalist organization called "Conscience Society." Though as yet no other authentic source corroborates this information, these documents present the characteristic outlook and behavior of the tsarist police toward any nationalistically-colored stir among the Crimean Tatars.
\end{abstract}

\title{
Résumé
}

Hakan Kirimli, L 'organisation nationaliste « Conscience » chez les Tatars de Crimée : une réalité ou une invention de la police?

On sait qu'au début des années 1910, il y avait un déploiement d'activités nationalistes clandestines parmi les Tatars de Crimée ; certaines d'entre elles étaient liées à la Société de la patrie fondée par les étudiants tatars de Crimée en Turquie. Les documents récemment découverts dans les archives de la police tsariste attribuent la plupart de ces activités en 1910 à une certaine organisation tatare de Crimée, appelée Conscience. Bien que jusqu'à présent aucune source authentique ne corrobore cette information, ces documents présentent l'attitude et le comportement caractéristiques de la police tsariste envers toute agitation de couleur nationaliste parmi les Tatars de Crimée. 


\section{THE CRIMEAN TATAR NATIONALIST ORGANIZATION "CONSCIENCE" : FACT OR POLICE INVENTION ? *}

The first decade of the twentieth century witnessed the appearance of the incipient, but concrete, fruits of the national awakening of Crimean Tatars in the intellectual and economic spheres. By then, thanks for the most part to the national reform drive of the renowned educator and thinker İsmail Bey Gaspıral , a seemingly modest but effective rejuvenation of the cultural and educational life of the Crimean Tatar society had already begun. A consequence of this was the emergence of a budding Crimean Tatar national intelligentsia which began to ponder about the state of affairs and problems of their society in a fundamentally different way from the previous generation.

The 1905 Revolution in the Russian Empire opened new prospects before the nationalistic and reformist-minded Crimean Tatars, who found themselves in a position where they could vent their long-suppressed grievances and demands from the government. On the one hand, taking the advantage of relative freedom, the reformists led by Gaspıralı initiated a dramatic broadening of the existent educational system in the native language. In addition to the expansion of the reformed Muslim primary schools (mekteps), for the first time under the tsarist rule, the Muslim secondary schools (rüscliyes) began to burgeon in most of the Crimean towns. In the latter, where the curriculum was in the native language, along with Muslim religious instruction, a number of secular subjects, including national history, was being taught. To provide the qualified teachers for these new schools who were not sufficiently available within the Crimea, teachers (most of whom belonged to Crimean Tatar immigrant families) were invited from Turkey for instructional leadership. A number of students were also sent to Turkey for further education.

During the same period, "Muslim Charitable Societies" (Musülman Cemiyet-i Hayriyeleri) were founded to sponsor these educational enterprises and to handle other public activities of the Crimean Tatar society. There was a tangible revitalization of the hitherto insulated society, and a significant broadening of its interests. More people were attracted to public activities and more people began to read newspapers and books. All-Crimean Muslim meetings were held, and deputations delivered collective petitions to St. Petersburg. Eminent members of the

* I would like to express my gratitude to Eldar Seytbekir for his assistance in preparing this article. 
Crimean Tatar society would come to join the activities of the All-Russian Muslim movement in which Gaspıralı was universally esteemed as its pathfinder.

On the other hand, though actively participating in these developments, a group of politically-minded young Tatar intellectuals were inclined to more radical drifts. They were profoundly nationalistic with somewhat vague socialistic leanings, and in the person of the tsarist autocracy, they saw the roots of every evil which caused the sufferings not only of their own people but those of the entire Russian Empire. As maintained by these "Young Tatars," nothing short of the overthrow of the autocracy by means of a "revolution" could bring salvation to the subjects of the Empire. On that account, they were willing to cooperate with the arch-enemies of the tsarist order, the Russian revolutionaries, particulary the Socialist Revolutionaries (SRs), and largely emulated the latter in their conspiratorial work. Thus, within a short time, the Young Tatars succeeded in establishing a network of underground circles and cells in several Crimean cities and villages.

Nevertheless, the liberties of 1905 proved to be ephemeral. As the tsarist administration recovered from the initial shock of revolutionary upheavals, it soon began to recant from its earlier concessions. Especially from 1907 onward, the autocracy for the most part resumed its accustomed oppressive position and brought developments under its control. Thus, many of the gains of the 1905 Revolution for the Crimean Tatars had to be surrendered. All rüşdiyes were closed down by 1910 , the Ottoman-citizen teachers were banned to teach in the Crimean mekteps, and the educational, cultural, and public activities of the Crimean Tatars were rigorously constricted by the tsarist administration. All "politically unreliable elements," such as the Young Tatars, were either arrested, banished, fired from their jobs or at best constantly watched by the police. Consequently, the Young Tatar movement, which had never become a close-knit organization, dissolved or at least lost its previous configuration by 1910. Some of the individual Young Tatar circles or cells, however, continued their existence clandestinely until 1917, by becoming a part of the later national movements. ${ }^{1}$

In the meantime, the seeds of a fresh national movement were sown among Crimean Tatar students in Turkey. Deeply affected by the new political atmosphere prevalent in the Ottoman Empire during and after the 1908 revolution, a group of Crimean Tatar students formed a study circle in which they discussed political issues concerning the Crimea. The outcome of this study circle's discussions was apart from a legal, broader-based and non-political Crimean Students Association, the clandestine and nationalistic "Fatherland Society" (Vatan Cemiyeti) which was founded in Istanbul en 1909. The founding members of the Fatherland Society were Noman Çelebi Cihan (1885-1918), Cafer Seydahmet [Kırımer] (1889-1960), Yakup Seytabdullah Kerçi, Ahmed Şükrü, and a few others. Soon several new members were to join them.

The Fatherland Society was purely political in motivation and conspiratorial in character. The members were coopted only after a thorough screening, and were organized in the form of five-man cells. The identities of the members of the central committee were kept strictly secret. The aims and tactics of the Fatherland Society were molded under the strong sway of the ideals of the victors of the Ottoman revolution, the Young Turks, as well as the European romantic nationalists, such as the Carbonari, about whom they read secondary literature available in post-1908 Istanbul. True to the inherited legacy of the Young Tatars, the Fatherland Society 
considered the tsarist autocracy as the arch-enemy and the latter's overthrow through a "revolution" as its prime objective. Although during the earlier phase of the Society's existence their concepts and aims remained rather vague, its members firmly believed that such a "revolution" would bring about the "liberation of their people." They differed from the Young Tatars who had been under the much stronger, if superficial, impact of the Russian Socialist Revolutionaries, as the Fatherland Society's intellectual breeding ground was more of the Young Turk (Union and Progress) milieu. ${ }^{2}$

Apart from agitation among the Crimean students in Istanbul, the members of the Fatherland Society engaged themselves in printing proclamations to be distributed secretly in the Crimea. ${ }^{3}$ Such proclamations were smuggled into the Crimea either by the ordinary mail or by individuals returning home. They were distributed among the Crimean intellectuals, in the medreses, and in the villages. In these proclamations the tsarist autocracy and its oppression, the abuse of the Crimean vakifs at the hands of the Russian chinovniki (tsarist officials), and the incompetence and obsequiousness of the Muslim Spiritual Board in the Crimea, among other factors, were criticized and the people were urged to struggle against them. ${ }^{4}$ The Society also smuggled into the Crimea hundreds of volumes of books and journals published in post-1908 Istanbul. Such publications were mostly books about revolutions and revolutionary organizations, religious and literary works, and Turkish and Islamic histories. The basic objective in sending those publications was to provide the teachers and other intellectuals with the necessary material so that they might be able to indoctrinate the people about the essence of the idea of revolution and their civil and national rights. 5 One of the publications sent to the Crimea was a pamphlet written by one of the leaders of the Society, Cafer Seydahmet, under the pseudonym "Şehab Nezihî." 6

Evidently, from 1910 onward, the Fatherland Society had already established connections and entrusted individuals inside the Crimea who distributed proclamations and literature received from Istanbul. One such member of the society was Alimseyit Cemil [Salkat] (1878-1964), the younger brother of the prominent "Young Tatar," Menseyit Cemil, who had returned to the Crimea in 1910 and had begun working as a teacher. ${ }^{7}$ Nevertheless, according to Cafer Seydahmet, it was no earlier than in 1912 that the Fatherland Society decided to organize a widespread network of cells inside the Crimea. ${ }^{8}$

Information about the activities of the Fatherland Society within the Crimea during the early 1910's is extremely scant. ${ }^{9}$ However, it is known that it was basically the leading members of the Fatherland Society who succeeded in taking Crimean Tatar affairs in the Crimea under their control very soon after the February Revolution in 1917, and who composed the leadership in the Kurultay (Crimean Tatar Parliament) which was to be convened in December 1917 and was to declare the Crimean Democratic Republic. The rapid and very thorough fashion in which they managed to take the initiative then suggests the pre-existence of an effective underground organization of the Fatherland Society inside the Crimea, which came to the surface when the opportune time arrived.

Conversely, the official Russian documents evince the existence of nationalist organizations or groups active in the Crimea as early as 1910 about whose relations with the Fatherland Society there exists no evidence. According to the reports of the 
tsarist gendarmerie, such activities "were observed among the Tatar people and especially among the intelligentsia and the teachers of the Tatar schools in 1910."10

Such reports particulary dwell on the alleged activities of a certain Crimean Tatar revolutionary-nationalist society called "Conscience" (in Russian: Sovest'; its Crimean Tatar name was not provided). Apparently, the tsarist police was first informed about the existence of a society under that name through the distribution of proclamations under the title "Conscience" in the mosques of Akmescit (Simferopol) in March 1910." Samples of these proclamations were delivered to the gubernator (governor) by the mufti of Tavrida, Adil Mirza Karaşayskiy. ${ }^{12}$ As it appeared, the proclamation was written by someone who must have been educated in Turkey. In fact, such sophisticated locutions of the text, which were replete with Arabic words little intelligible to the local Crimean Tatars, caused problems for the police who had to employ four different translators to obtain a reasonably understandable Russian translation. ${ }^{13}$

Indeed, even the Russian translation of the proclamation reveals its characteristic semi-popular and semi-learned Ottoman style. It was entitled "Conscience" and bore the date March 1910. The first sentence of the proclamation, which was numerated as "no. 1," warranted the intention that it would be published every month under this title "for the purpose of defending the rights of the Muslims." Having referred to the past glorious days of the Muslims, it deeply resented the contemporary situation in which the Muslims suffered under Russian rule:

\footnotetext{
"Hoping for a candidly affectionate treatment on the part of the government, the poor Muslims take pains to display their loyalty even more than the very Christian Russians do. We are a handful of Muslims, but we live in enmity with each other. It is very deplorable that so far there has never been a party which worked for the benefit of Islam. The present [Muslim] parties have associated themselves with the Christian union, therefore the desired benefit and the necessary treatment of our diseases have not been achieved. Apparently we have a newspaper, but it is busy with settling personal accounts or with trifles. There are the ulema, the religious scholars, who are busy [only] with religious matters; there are the mekteps which are fully subject to the ignorance of their five-rubleworth members. There is no life in a single field; hypocrisy and provocation have ruined us. If the life of the Muslims goes on as such, it cannot last longer than ten more years. Just recently we have seen such scoundrels who, strolling like the dogs of the Emperor, sold out the lives of their co-religionists.

In order to bring an end to this situation, a few people who are devoted to their faith and nation gathered together and reached the conclusion that the sole remedy for our diseases is unity. Having sworn on God and the Prophet, they piously promised to work in the name of Islam and set up a society under the name 'Conscience,' whose aim will be to toil, till the last days of their lives, for the liberation of the Muslims from distress and to safeguard the rights of their brothers with a clean heart, without being afraid of the impediments."
}

The proclamation went on exhorting for the essentiality of unity and solidarity, and warned against the spies, traitors, and renegades from within the Muslim community whom the Society was to expose and, when necessary, was to punish. All peoples acquired their national rights and nothing could prevent this. Therefore, through solidarity and labor, God willing, they could "reestablish the Muscovite [sic] khanate of our ancestors." 14 
The initial impression given by the wording of the proclamation may lead to a misconception of its basic intentions. Notwithstanding the fact that when referred to, "our nation" used only the appellation "Muslim," it did not mean in any way "PanIslamism." Within the context of the contemporary intellectual, and given social circumstances, this was the more common form of referring to "our nation" which in the broader sense meant the Muslim (Turkic) subjects of the Russian Empire in general, and the Crimean Muslims (Tatars) in particular. After all, the situation described and the audience addressed in the proclamation were purely Crimean in content. The aspiration towards the "re-establishment of the Muscovite khanate" (if it was not a matter of incorrect translation) must have denoted a yearning for the times of the Golden Horde when the mutual roles of the Russians and the Turks (Muslims) had been just the opposite. However, a clear aspiration towards a form of independence from the Russian rule is manifest in the proclamation, and this seems to be one of the earliest overt statements concerning the issue within the contemporary Crimean Tatar nationalistic/revolutionary movements.

Naturally the discovery of such a proclamation led to a vigorous investigation on the part of the tsarist police, who interpreted the contents of the text as the foundation of a Tatar society "whose aims of its activities in the Crimea [were] the spread of Tatar national-cultural conscience and the education of the Tatars in the spirit of antagonism against Russia and the government." Similarly, it was supposed that their ultimate objective was "establishing an independent (samostoiatel'nyi) Tatar tsardom of Russia." 15 In time, the latter was to be construed as striving "toward the establishment of an independent Crimean khanate." 16

Initially the language problem, as well as no discernible affiliation with any other (Russian) revolutionary organization, created complications for the police in obtaining healthy information, though a collaborator (sotrudnik), apparently not a member of the alleged society, could be found. ${ }^{17}$ It took some months after the discovery of the proclamation to identify its suspected author and the leader of the society. The suspect was a teacher named Mustafa Kurtzade or Mustafa Kurtnureddin. ${ }^{18}$ It was he who had written the first proclamations of the "Conscience Society" and having printed them hectographically, he personally distributed them in Bahçesaray and in the mosques of Akmescit in March 1910. ${ }^{19}$ According to the somewhat contradictory information acquired then and later, Mustafa Kurtnureddin (Kurtzade) was an Ottoman citizen (his name with the characteristic epithet "Kurt" suggests that he was almost certainly a Crimean Tatar, either a son of immigrants to Turkey, or someone who had subsequently acquired Ottoman citizenship). He had been a student in a military school in Istanbul, but having committed a sort of a breach of the law (probably a political transgression), he had fled to Russia (Crimea) and was wanted by the Ottoman government. ${ }^{20}$ He had appealed for Russian citizenship in 1908 and the result of this appeal was uncertain. ${ }^{21}$ In the Crimea, he was employed as a teacher in the rüsdiye of A kmescit until the latter's closure by the government in 1909. While teaching in the rüşdiye, allegedly "he had secretly instructed senior students about the histories of Turkey and the Crimean khanate," by "agitating that it was necessary to re-establish the Crimean khanate and that it must be under the protectorate of Turkey." He had also told the students to spread these ideas among the people when they went back to their villages. ${ }^{22}$ Having left Akmescit he moved to the village of Korbek near Aluşta and lived there in the house of Ismail Bayasanoglu "ostensibly as a tutor for the latter's children." He frequently traveled 
to the villages for the purpose of agitation and "his suitcase was full of proclamations." 23

According to the reports of the police agents, the center of the "Conscience Society" was in Akmescit, ${ }^{24}$ and most of the alleged members of the Society were mektep teachers, some of whom were Ottoman subjects. ${ }^{25}$ The initial agent reports identified the leading members of the Society as such: in Akmescit, the rüssdiye teachers Şükrü Efendi (Ottoman citizen) and Abdül Efendi (Russian citizen); in Aluşta, teachers Amdi Efendi and Ismail Mirza Arabskiy ; in Kefe (Feodosiia), the former teacher of the Ministerial Tatar School, Menseyit Cemil; in Karasubazar, the rüscliye teachers Yusuf Ziya Efendi and Fevzi Efendi (both Ottoman citizens); in the village of Korbek (Yalta uezd), teacher Abdülalim Efendi (Russian citizen); and in the village of Degirmenköy, teacher Acı Bekir Efendi (Russian citizen). Apart from these, there were two unidentified printing house workers in Bahçesaray who were in charge of the typographical works of the Society and also Appaz Mirza Şirinskiy who traveled to Istanbul in early July in order to bring back literature. Some of these alleged members of the "Conscience Society" were reported to say that the Society had many proponents among the Tatar youth and their work was successful. ${ }^{26}$ Another report names Hasan Sabri Ayvazov, a prominent Crimean Tatar writer and activist from Alupka, among the members of the Society. There, it was also stated that Ayvazov had addressed a large group of Crimean Tatars in Aluşta in June where he talked about "the necessity of unity and solidarity and fighting against the Russian government to reach their ultimate goal of establishing an independent Muslim state." To this end, the immediate duty of the Crimean Tatars had been preventing at all costs, the "closing of existing Turkish political [sic] schools [i.e., the rüssdiyes in the Crimea]" since the graduates of these schools would perform great services for the Tatars. ${ }^{27}$

Among the above-mentioned "members of the Conscience Society" were quite a few who where known as the prominent figures of the previous Young Tatar movement. For example, Appaz Mirza Şirinskiy, a scion of the most important family/clan (the Şırıns) in Crimean Tatar history, had been one of the earliest figures to be involved in revolutionary activities in connection with the Russian revolutionaries, and a founding member of the Young Tatar movement. His name was, of course, well known by the police. ${ }^{28}$ So was the name of Menseyit Cemil, another leading "Young Tatar" who had actively participated in the revolutionary events of 1905 and had had close relations with the Russian SRs. He was known to be a "fervent nationalist" and an effective agitator among the Crimean Tatars. On the pretext of his "political unreliability," he had been fired from his job as a teacher, and currently he was dealing with fruit trade in Eskikırım. ${ }^{29}$ Another conspicuous "Young Tatar" was Hasan Sabri Ayvazov who had been the editorial writer of the Young Tatar paper Vatan Hâdimi and one of the chief theoreticians of Young Tatar thought. ${ }^{30}$ In addition, the names of Yusuf Ziya Efendi, the founder and director of the Karasubazar rüssdiye and a protégé of Abdürreşid Mehdi, the leader of the Young Tatar movement, and İsmail Mirza Arabskiy had been closely associated with the Young Tatar movement. ${ }^{31}$ In fact, the Young Tatar movement had been composed largely of radical/nationalistic-minded teachers, and the others whose names were on the list of the tsarist police were also teachers (especially the rüssdiye teachers), many of whom quite possibly might have had some connections with the Young Tatar movement during the preceding years. 
Thus, the presence of so many Young Tatars among the alleged members of the Conscience Society raises a number of questions and possibilities. One possibility is that, upon the discovery of the existence of a new clandestine Crimean Tatar nationalist organization, in search of its members, police agents and informers must have turned their attention to the already-known radical/nationalists, i.e., the [ex-] Young Tatars first. It is not surprising that, under such circumstances, the members of the Young Tatar movement would be considered as automatic suspects who, with their previous activities and convictions, stood out among the traditionalistic-minded Crimean Tatars. Furthermore, the mere fact of being a teacher in a reformed mektep, particulary in a rüscliye, not to mention also being an Ottoman citizen, was more than enough to attract the alertness of the tsarist police which habitually deemed them as actual or potential propagators of Pan-Islamism, Pan-Turkism, nationalism, socialism, and every other sort of "politically undesirable" ideas. This was not totally baseless however, as most of the protagonists and promoters of Crimean Tatar reformist, revolutionary, and nationalistic movements had indeed been such teachers. Therefore, the teachers were almost always the natural suspects in case of any politically-colored stir among the Crimean Tatars.

It is also possible that at least some of the ex-Young Tatars might have sought a re-organization by reassembling their fellow travelers in the form of the "Conscience Society." After all, the Young Tatar movement certainly had not abruptly ceased to exist and many of its adherents did not withdraw themselves from various forms of social or political activities at all. Apparently, neither did they change their previous fundamental convictions.

Constituting the dynamic segment of the Crimean Tatar intelligentsia, such intellectuals (ex-Young Tatars or not) were expected to be sensitive and vocal towards the current concerns of the Crimean Tatar society. A pressing concern in the Crimea in 1909-1910 was the government's decision to close down the rüscliyes, refusing their status as unauthorized autonomous Crimean Tatar national educational institutions. Naturally, all Crimean Tatar reformists and intellectuals energetically protested this decision, though to no avail. Those intellectuals who openly enunciated their remonstrance against the government's decision must have been taken note of by police agents or informers as the possible members of a new Crimean Tatar nationalist society.

In June 1910, proclamations written in Crimean Tatar and titled "Conscience" were once again left in an Akmescit mosque. ${ }^{32}$ During a meeting with the Crimean Tatar notables about the fate of the rïscliyes on 2 July 1910,* the gubernator complained about the distribution of proclamations in several places, about which he had been informed by Muslim informers. ${ }^{33}$ As it appears, the police archives do not contain the text of the second (if it was different from the first) proclamation.

The police were also informed about the impending clandestine conference of the Conscience Society to be held sometime in July. In fact, it was due to this information that instructions were sent to the local gendarmerie offices to the effect that the above-mentioned suspects should not be arrested or interrogated so that all identified and yet-unidentified members could be rounded up during the conference. The police

\footnotetext{
* Throughout this article all dates were quoted in accordance with the standard Gregorian calendar. While citing the official documents, however, their dates werc left unconverted (i.e., in Julian calendar) as they appeared on the original text. The Gregorian calendar is 13 days ahead of the Julian calendar in the twentieth century.
} 
expected to be informed about the date and place of the conference by its collaborator in advance. ${ }^{34}$ However, in spite of his earlier promises, the collaborator was only able to bring his report about the conference three days after it actually took place. ${ }^{35}$ Thus nobody could be caught. The meeting was held at the Sarıül Station on the southern railway near Kefe (Feodosiia) on 30 July 1910, with the participation of fifteen members. Among them the names of the following were identified: from Aluşta, teachers İsmail Mirza Arabskiy and Amdi Efendi; from Eskikırım, Menseyit Cemil; from the village of Dereköy (Yalta uezd), teacher Mustafa Kurtnureddin; from the village of Süyrütaş (Yalta uezd), Abdülaziz Efendi; and from Karasubazar, teacher Yusuf Ziya. The conference was chaired by Eşref Efendi.The agent's report about the conference also stated that the activities of the Conscience Society were very effective and widespread in the villages of the uezd of Kefe. ${ }^{36}$

Incidentally, Eşref Efendi was not a well-known figure by the police. From the precursory information it appeared that he was an Ottoman citizen and was (or had been) teaching in a rüsdiye. Although he was said to reside in Kerç, ${ }^{37}$ the subsequent information from Kerç did not corroborate this. ${ }^{38}$ Another report located him in the village of Salın (Saraymen volost', Kefe uezd) living in the house of Selim Hac1 Efendi, another rüssdiye teacher. ${ }^{39}$

As repeated orders were sent to the local authorities for more information about the members of the Society and to the effect that they be put under close observation, several intelligence reports began to pour in. According to these reports, the Conscience Society had members (or representatives) in the cities of Akmescit, Kerç, Aluşta, Karasubazar, Eskikırım, Alupka, and Bahçesaray, in the villages of Korbek, Degirmenköy, and Süyrütaş in the uezd of Yalta, and in some of the yet unknown villages in the uezd of Kefe. ${ }^{40}$ It was also reported that, apart from such members, Crimean Tatar pupils were also put to work, sometimes upon payment, to disseminate proclamations in the villages. ${ }^{41}$

New names continued to be added to the list of alleged members of the Conscience Society. They included "among the organizers of the party," the rïsdiye teacher Seytabdulla Alioglu and Mehmed Riza Murtazaoglu (Ottoman citizen) in Akmescit, and "an active member" university student Davidoviç, son of Mustafa Mirza Davidoviç, the ex-mayor of Bahçesaray, in Aluşta. There were even the names of such persons as a certain Ivan (a Russian socialist) and a Polish socialist, as well as Moishe Isaakov-Sultanskiy (obviously a Jew or a Karaim). ${ }^{42}$ Given the complexion of the Conscience Society as reflected in the police reports, the membership of particularly these last persons seems all the more implausible. Not surprisingly, in addition to these "identified members," several persons with whom they had personal relations were also recorded in the police reports. Although there were suspicions by the police about the Society's connections with Turkey, no concrete evidence could be found. The only intelligence item on that matter was that Süleyman Efendi, a member of the Conscience Society and a teacher from Sudak, had allegedly been sent to Istanbul by the Society to deal with the transmission of publications from Turkey to the Crimea. ${ }^{43}$

Finally, confiding in the identification of most of the members of the Conscience Society, the Crimean (Tavrida) Gendarmerie Administration decided to act and to "liquidate" the Society. To that effect, orders were given to undertake mass searches in the residences of the suspects all over the Crimea on the night of 29 September $1910 .^{44}$ 
Nevertheless, these mass searches proved to be a disappointment to the police as they did not produce a satisfactory amount of incriminating evidence against, and documents about, the Society. In the houses of Ömer Mirza Mansurskiy, Mambet Ayedinov, and the teacher Ismail Kerimcanov (Firdevs; he was to become the first Crimean Tatar Bolshevik in 1917) a total sum of eight banned socialist books in Russian were found. An SR proclamation dated 1907 in the Crimean Tatar language was also discovered at the home of Mehmed Riza Murtazaoglu. ${ }^{45}$ As for Mustafa Kurtnureddin, the alleged founder of the Conscience Society, the police were able to find in the place where he lived only twenty copies of a proclamation in Turkish which called for donations to the Turkish navy. ${ }^{46}$ (It seems that these proclamations must have to do with the contemporary navy donation campaign [Donanma lânâtı] in the Ottoman Empire.)

The disappointing findings of the mass searches raised doubts about the previous inferences of the tsarist police. In fact, aside from the copies of one or two proclamations, almost all information and evidence were confined to the unconfirmed statements of a few Tatar informers. Unlike the case with the Russian underground socialist organizations and parties into which the tsarist secret police was usually successful in installing stool pigeons and agents, evidently it proved much more difficult to find reliable and well-trained collaborators for the Crimean Tatar nationalist organizations. Within such a small and quite closely-knit society with an alien language, religion, culture, and traditions where an outsider would have immediately been descried, non-natives would have been totally useless for purposes of penetrating into a nationalist organization. Therefore, it was imperative for the police to rely upon the attestations of whichever Crimean Tatar informers were available. Yet apparently, few such local Tatar informers had any respectable standing within the community, let alone a reasonable degree of political conversance. All they could do was for the most part frequent the local coffeehouses and listen in on conversations. Certainly, anyone who talked about political or intellectual subjects or who had enjoyed a degree of influence due to his education or had any personal connections with Turkey, was of particular interest to such informers. Thus, without much evaluation they hurried to present reports full of contradictory and implausible information.

In fact, the tsarist police came to realize this and frequently accepted the less than qualified properties of the informers. A characteristic case was that of a local Tatar informer nicknamed "Beetle" ("Zhuk"). The Gendarmerie Administration considered him a man "who did not have a sober way-of-life" and a "useless agent [...] who fabricated false information." It was "Beetle" who had denounced at least twenty-three people by name in connection with a "Tatar society [Conscience] whose influence spread all over the Crimea and which, conducting active agitation, collected huge sums for Turkey to be used in a prospective war against Russia." $\mathrm{He}$ had also claimed that "all Tatars adhered to the program of the Social Democratic [Workers'] Party" and even people like Gaspiralı and Mehdi had openly declared this adherence! ${ }^{47}$ The inconceivable nature of "Beetle"'s information and the low opinion of the police about his personality, and the dubiousness of his reports notwithstanding, his services still could not be rejected as he had provided the longest single report about the "Conscience Society." Indeed, the persons denounced by "Beetle" were put under police observation. ${ }^{48}$ 
In the face of the lack of any hard evidence and having failed to corroborate the hitherto collected data, by late October 1910, the police professed doubts about the very existence of the "Conscience Society." 49 It seems that little further information was received about the alleged organization. One such report was about the teachers Mustafa Kurtnureddin and Amdi Aktotay who, at a dinner hosted by Hasan Sabri Ayvazov in Aluşta in November 1910, allegedly talked about the persecution of the Crimean Tatars, and sang together the Turkish revolutionary song "Hürriyet" (Liberty) while raising their toasts to the health of the Young Turks and the new Ottoman sultan, Mehmed V Reşad. ${ }^{50}$

Apparently, the tsarist police did not receive any significant information about the activities of the "Conscience Society" after 1910. Those whose names had been involved in the case, however, were not forgotten. Although no legal proceedings could be started against them due to the lack of any conclusive evidence, the presence of their names in police records continued to create troubles for them in later years. For example, on 27 December 1910, the Police Department asked for an order of the gubernator to expel Mustafa Kurtnureddin from Russia. ${ }^{51}$ For some reason, this order could not be carried out, and on 27 October 1911, the Police Department repeated its request for permission to expel him and to take a photograph of him in order that he never enter the Russian Empire again. ${ }^{52}$

Even in 1914 such records proved detrimental for the suspects. The name of Amet Acr Amzaoglu, a teacher who had received his education in Turkey and had returned to the Crimea in 1910, had been cited in the records in connection with the "Conscience Society" in Alușta. No evidence of any criminal activity had been found during the search of his house, and the Yalta uezd police officer testified to his "good behavior and that he had not been prosecuted." All the same, owing to the previous allegations, he was considered "politically unreliable" and was denied permission to work as a teacher in the village of Korbek in 1914.53

At least in one case it is known that allegations of membership in the "Conscience Society" were false. In September 1912, Halim Baliç, a reformist-minded teacher in the village of Degirmenköy, in the uezd of Yalta, was banned from teaching on the grounds that his membership in the "Conscience Society" had been discovered and that he had been present at the secret meeting of the Society on 28 September 1910, in Kefe. ${ }^{54}$ Yet, more than two decades later, Halim Baliç, who otherwise made no secret of his actual nationalistic activities then, disavowed any knowledge of such a society and his alleged participation in any meeting held in Kefe in 1910. He stated that the only reason for these charges were to create a subterfuge to remove him from his job. ${ }^{55}$

Despite the fact that the tsarist police, as well as relevant government offices dealing with Crimean Tatar affairs (e.g., educational and religious matters), were preoccupied with dissolving the activities of an alleged "Conscience Society" (particulary in 1910), what in reality that Society was or whether it ever existed still remains unsettled.

It is true that so many persons (mostly the "usual suspects," such as teachers and other intellectuals) were specified as members or proponents of the Society, but only due to questionable intelligence reports and denounciations. Besides, most of these suspects were associated with serious illegal activities, and the estimated scope of their actions created intense apprehensions within the local officialdom. It remains, however, that no conclusive evidence could be found in spite of all efforts and it 
appears that there was no one person caught red-handed in connection with the case nor did a single person avow his membership in such a society. Aside from one or two anonymous proclamations, all charges were based on circumstantial, if not controvertible, evidence.

The enigma about the "Conscience Society" becomes even more complicated as none of the available Crimean Tatar sources corroborate the existence of that organization, at least not under the name mentioned by the tsarist police and gendarmerie. Another enigmatic factor is that the Crimean Tatar name of that organization, if it ever existed, is not available. It is noteworthy that most of the alleged front runners of the "Conscience Society" are not well-known figures in the general Crimean Tatar national movement. (The exception could be the ex-Young Tatars, but they had stood out during the preceding years rather than in the future movements, save for Hasan Sabri Ayvazov.)

This is not to postulate, however, that all information and perceptions of the tsarist police about the ongoing developments among the Crimean Tatars were baseless. It is possible, though yet-to-be-substantiated, that the real or alleged activities of what were in all likelihood diverse Crimean Tatar nationalistic groups and individuals (perhaps including those related to the Fatherland Society) might have been generally attributed to that particular organization, which was referred to under the name which somehow appeared on some proclamations in 1910. Indeed, the preceding and the subsequent trends of the Crimean Tatar national movements strongly suggest the existence of underground circles and some other kind of organizations among like-minded intellectuals during the early 1910's, and 1910 in particular. Such groups would have constituted the historical link, or a kind of a transition, between the Young Tatars and the Fatherland Society. In any case, it was thanks to an already present infrastructure that the Fatherland Society found a fertile ground to expand their activities and sympathizers within the Crimea prior to the First World War.

Although the year 1910 is often deemed to be a year when the then vocal Muslim revolutionary/nationalistic groups (such as the Young Tatars) succumbed to the increasing reaction of the tsarist regime, it also represents a period when the aftereffects of the Young Turk revolution in 1908 had clearly reached the Turkic/Muslims of the Russian Empire. Possibly in conjunction with such external influences, the stir among the Crimean Tatar intelligentsia, as reflected in the police records, might also evince the presence of a sensitivity against the current repressive measures of the autocracy, especially against those which hit close to home, such as the closing of the rïşdiyes. In fact, certain phrases of the "Conscience" proclamation and the general allegations suggest a growing concern and participation of the new Crimean Tatar intelligentsia with a nationalistic, if ill-defined, outlook in the national/societal matters.

On the other hand, the case of the "Conscience Society" illustrates the tsarist police's dealings with, and worries about the Crimean Tatar intelligentsia, and especially reformist-minded teachers, in its characteristic way. As if by definition, the tsarist police saw in every Crimean Tatar teacher of reformed Muslim schools (particulary those who had some connections with Turkey), a potential enemy of the Russian state and was determined to put an end to their educational activities at the first opportunity. It is clear that the police had difficulties penetrating into the inner circles of the Crimean Tatar nationalists and had to rely upon the common hearsay 
provided by questionable informers. All the same, any suspicion of a nationalistic and/or political activity, even if it was not well-founded, was exploited to further curb the gains of the Crimean Tatar society in the 1905 Revolution.

As yet much remains to be unearthed in order to ascertain an accurate picture of the Crimean Tatar nationalistic activities in the early 1910's within the Crimea. Though with a cautious and critical approach, the fragmentary information recorded by the tsarist police in conjunction with the case of the "Conscience Society" (whether it existed or not) might shed light upon a relatively less-elucidated period of the general Crimean Tatar national movement, hopefully with the disclosure of further complementary Crimean Tatar and Russian documents.

\section{Bilkent University; Ankara, 1995.}

1. For the impact of the 1905 Revolution on the Crimean Tatar society and for the "Young Tatar" movement, see S. Hakan Kırınlı, National movements and national identity among the Crimean Tatars, 1905-1916, E.J. Brill, Leiden, 1996.

2. For the foundation of the Fatherland Society, see ibid.: 226-234; Cafer Seydahmet Kınmer, "Bazı Hatıralar," Emel, 5, suppl.: 30-32; 6 suppl.: 33-40; 7, suppl.: 41-48; 8, suppl.: 49-56; Edige Kırımal, Der nationale Kampf der Krimtürken (Emsdetten/Westfalen, 1952): 24-28; Alimseyit Cemil Salkat, "Kırımlı Alim Seyit Cemil Efendi'nin Hatıratı," manuscript (recorded by Edige Kırımal in Alberschwende/Austria in July 1948), Personal Archives of İsmail Otar (lstanbul): 1-2, 7.

3. Ibid.: 2.

4. C.S. Kırımer, art. cit., 8: 40; id., "Cafer Seydahmet Bey'in Nutku," Emel Mecmuası [Constanza, Romania], $11-12$ (1935): 86-87.

5. A.S. Salkat, $o p$. cit.: 7.

6. Şehab Nezihi, Yirminci Asırda Tatar Millet-i Mazlumesi (Istanbul, 1328/1910).

7. Salkat's activities soon attracted the attention of the police who searched his house and mektep nine times between 1910-1914 (A.S. Salkat, op. cit.: 2).

8. C.S. Kirimer, "Cafer Seydahmet...," art. cit.: 88.

9. In fact, almost all primary information about the Fatherland Society comes from the memoirs of Cafer Seydahmet Kirimer and those of the very few other members of the Society, such as Alimseyit Cemil Salkat.

10. Arslan Nayman Mirza Oleshkevich Krichinskii, Ocherki russkoi politiki na okrainakh. I: K istorii religioznykh pritesnenii krymskikh tatar (hereafter Krichinskii I) (Baku, 1919), appendix: 283.

11. A.N.M.O. Krichinskii, Ocherki politiki rossiiskogo tsarizma na okrainakh. II: $K$ istorii bor'by $s$ prosveshchenicm i kul turoi krymskikh tatar (hereafter Krichinskii II) (Baku, 1920), appendix: 129.

12. "From Colonel Nemirovich-Danchenko, chief of the Gendarmerie Administration of Tavrida guberniia to the Police Department, ? June 1910," Tsentral'nyi Gosudarstvennyi Arkhiv Kryma (hereafter TsGA Kr.), Akmescit (Simferopol), f. 706, op. 1, d. 329.

13. Ibid. Regrettably, the Crimean Tatar original of the proclamation does not seem to be preserved in the tsarist archives.

14. "Sovest'," TsGA Kr., t. 706, op. 1, d. 306.

15. "From Colonel Nemirovich-Danchenko to the gubernator of Tavrida, 20 September 1910," TsGA Kr., f. 706, op. 1, d. 329.

16. Krichinskii II, app.: 129.

17. "From Colonel Nemirovich-Danchenko to the Police Department, ? July 1910," TsGA Kr., f. 706, op. 1, d. 329.

18. "From Captain (rotmistr) Leus to the deputy chief of Sevastopol Gendarmerie Administration in the uezd of Yalta, 23 July 1910," TsGA Kr., f. 706, op. 1, d. 329.

19. Krichinskii II, app.: 129.

20. "From Colonel Nemirovich-Danchenko to the Police Department, 24 July 1910," TsGA Kr., f. 706, op. 1, d. 329. His previous relationship with the Ottoman military school was further corroborated by the 
facts that, while in the Crimea, he continued to wear a red Ottoman fez and a military overcoat with yellow metallic buttons and that in his possession was a (ceremonial?) sword with inscriptions in Arabic alphabet on it. Ibid.

21. "To the Police Department, ? July 1910," TsGA Kr., f. 706, op. 1, d. 329.

22. Krichinskii II, app.: 129. According to another agent's infornation he left his job at the school in June 1909 on pretext of his ill health, but in reality for being able to deal more freely with the "revolutionary activities." " To the Police Department, ? July 1910," quoted.

23. "From Captain Leus..., 23 July 1910," and 7 August 1910 quoted. In the last document there is also infonnation that having heard about the rumors that the Russian government had leaned about "his criminal activities" he had written a petition asking for permission to return to Turkey and after his request had been granted, he had gone to Turkey. However, the subsequent reports do not corroborate this, as he was reported still in the Crimea later.

24. "From the Chief of Sevastopol Okhrana Department to the Chief of Tavrida Gendarmerie Administration, 27 September 1910," TsGA Kr., f. 706, op. 1, d. 329.

25. "From Colonel Nemirovich-Danchenko..., 20 September 1910," quoted.

26. "To the Police Department, ? July 1910," quoted.

27. "From Captain Leus..., 13 July 1910," quoted and "From Colonel Nemirovich-Danchenko..., 23 July 1910," quoted.

28. "To the Police Department, ? July 1910," quoted.

29. "From Captain Leus to the Deputy Chief of Tavrida Gendarmerie Administration in the uezd of Feodosiia, 8 July 1910," and "From the Deputy Chief of Tavrida Gendarmeric Administration in the uezd of Feodosiia to the Chief of the Tavrida Gendarmerie Administration, 12 July 1910," TsGA Kr., f. 706, op. 1, d. 329. It is significant that although Menseyit Cemil was quoted as "a very serious propagandist and agitator of the Conscience Society" and his movements were kept under observation, these police reports also state that "no evidence against him was obtained" apart from the information about his activities in the past and about his "political unreliability."

30. For a brief bibliography of Hasan Sabri Ayvazov (until 1918), see "Hasan Sabri Ayvazov," Kırım Mecmuasi [Istanbul], 9 (1918) : 169-170.

31. See S.H. Kırımli, op. cit. : 107, 203.

32. Krichinskii II, app. : 283.

33. "Kının`da Rüşdiye Mektepleri," Teârrüf-ü Müslîmîn [Istanbul], 8 (8 July 1326/1910): 135.

34. "From Captain Leus to the Deputy Chief of Sevastopol Gendarmerie Administration in the Yalta uezd, 8 July 1910," TsGA Kr., f. 706, op. 1, d. 32 and "To the Police Department, ? July 1910," quoted.

35. "From Colonel Nemirovich-Danchenko to the Police Department, 11 August 1910," TsGA Kr., f. 706 , op. 1 , d. 329.

36. "From Captain Leus to the Deputy Chief of the Gendarmeric Administration in the Kerç-Yenikale City Administration (gradonachal'st'o), 23 July 1910," TsGA Kr., f. 706, op. 1, d. 329.

37. Ihid.

38. "From the Deputy Chief of the Gendarmerie Administration in the Kerç-Yenikale City Administration (gradonachal stvo) to the Chief of Sevastopol Okhrana Department, 31 July 1910," TsGA Kr., f. 706 , op. 1, d. 329.

39. "From Colonel Nemirovich-Danchenko to his Deputy in the uezd of Feodosiia, 2 August 1910," TsGA Kr., t. 706, op. 1, d. 329.

40. "From the Chief of Sevastopol Okhrana Department to the Chief of Taurida Gendarmerie Administration, 24 July 1910," TsGA Kr., f. 706, op. 1, d. 329.

41. "From Captain Leus to the Deputy Chief of Sevastopol Gendannerie Administration in the uezd of Yalta, 7 August 1910," TsGA Kr., f. 706, op. 1, d. 329.

42. "From Captain Leus to the Deputy Chief of Sevastopol Gendarmerie Administration in the uezd of Yalta, ? August 1910," and "'Resolution' of Colonel Nemirovich-Danchenko," TsGA Kr., f. 706, op. 1, d. 329.

43. "From Captain Leus to the Deputy Chief of the Gendarmerie Administration in the ued of Feodosiia. 4 August 1910," TsGA Kr., f. 706, op. 1, d. 329.

44. "Resolution' of Colonel Nemirovich-Danchenko," quoted.

45. "From Colonel Nemirovich-Danchenko to the Chief of Sevastopol Okhrana Department, 29 September 1910." TSGA Kr., f. 706, op. 1, d. 329.

46. Krichinskii I, app.: 284; Krichinskii II, app.: 130.

47. "From the Deputy Chief of the Gendarmerie Administration in Kerç-Yenikale..., 31 July 1910," quoted. 
48. "From Colonel Nemirovich-Danchenko to the Deputy Chief of Tavrida Gendarmerie Administration in the llezd of Feodosiia, 2 August 1910," TsGA Kr., f. 706, op. 1, d. 329.

49. "From the Police Department to the Chief of Tavrida Gendarmerie Administration, 15 October 1910," TsGA Kr., f. 706, op. 1, d. 329.

50. "From the Deputy Chief of Sevastopol Gendarmerie Administration to the Chief of Tavrida Gendarmeric Administration, 9 December 1910," TsGA Kr., f. 706, op. 1, d. 329.

51. Krichinskii II, app.: 128.

52. Ibid., app.: 130.

53. Ibid., app.: 154-156.

54. Krichinskii I, app.: 151 .

55. Kırımlı Abdullahoğlu Hasan [Ortekin], "Kırın Türk Tarihi Yazmalarının İmhasında Rus Barbarlığı," Azerbaycan Yurt Bilgisi [Istanbul], 13 (1933): 39. 